calomel-and-opium; but towards the evening, more decided marks of peritonitis were found, as tension of abdomen, increased pain on pressure, with vomiting and frequent pulse. The abdomen was leeched, and the opium-and-calomel were more vigorously employed down to the evening of the 2nd of July, when these symptoms subsided, and in two days more the woman advanced to convalescence.

Dr. Merriman, in his synopsis of the various kinds of difficult parturition, refers to the history of eighteen such cases in the Medico.Chirurgical Transactions, and shows that nine of the women died, and three recovered imperfectly, while of twenty children making the produce of these eighteen labours, only four were born alive. Three of these cases were treated by opening the tumours, and afterwards leaving the labours to nature, with the result of two perfect recoveries and one incomplete one on the part of the mothers, and the preservation of two children; thus showing the advantage of this plan of treatment as compared to the various proceedings taken in the fifteen other cases.

I have no opportunity of referring to the several numbers of the Transactions alluded to, in order to ascertain if the tumour in any case was opened by the rectum, and this is my reason for making this communication.

In the case which I have related, the lowness of the tumour as examined by this canal, together with the fact that here only could be perceived a fluctuation, furnished my chief guide for the selection of puncturing through the rectum.

St. Columb, July 6, 1849.

\section{ON AN INSTANCE OF}

\section{EMPHYSEMA OF THE NECK AS A TERMINATION} OF HOOPING-COUGH.

BY W. BIRD HERAPATH, M.B.LoND., M.R.C.S.E., \&c., - CONGULTING SURGEON-ACCOUCHEUR TO THE GRISTOL-DISPENSARY.

\section{To the Editor of The Lancer.}

Srn,-I send you the enclosed for insertion in your valuable journal. Emphysema of the lung is by no means an uncommon occurrence in hooping-cough, but $I$ am not aware that air has been found in the cellular tissue of the neck by more than two observers, therefore this case is valuable and worthy of record. It is not impossible that it may have occurred more frequently, but that the observers have not published their cases: to all to whom $I$ have related the circumstance it has appeared novel and extraordinary.

I remain, dear Sir, yours most obediently, William Bird Herapath.

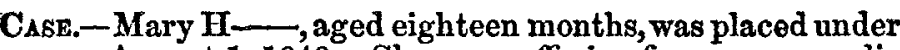
my care, August 1, 1848. She was suffering from a spasmodic cough, with an occasional whoop of an indistinct kind; symptoms of bronchitis also existed at this time. She was ordered to have two leeches on the sternum, and small doses of tartarized antimony at short intervals.

The bronchitis was controlled in the course of four or five days by persisting in this treatment; the febrile symptoms diminished; and the whoop became more fully formed. The antimony was continued, but at longer intervals, during the whole of the subsequent week, in consequence of which the cough became less teasing and troublesome, and by the 15th, the whoop had almost entirely disappeared, but the spasmodic cough remained at this time. All fever had vanished. The child had lost its appetite, and its strength was considerably diminished; the pulse was small, weak, and rapid; the respirations were short and frequent, and more dyspnœa existed than the symptoms warranted; but little mucous râle remained; the face was pale and exsanguine; the lips almost white. I prescribed one grain of the citrate of iron and quinine three times a day.

No improvemnt resulted; the dyspncea steadily and rapidly progressed; the axillary muscles of respiration were brought into play; but the countenance did not become livid until after a fit of coughing; the chest sounded well on percussion everywhere. I at first attributed this dyspnoea to excitement, unti the friends assured me she was always so. The cough was almost nothing at this period; it was readily smothered by the child.

On the 17th of August, after a more than usually violent fit of coughing, a swelling made its appearance in the neck, just over the sternum; the depression between the origins of the sterno-mastoid muscles disappeared, and was converted, in shape and appearance, into an enormous goitre; but the boun- daries were more diffused and extensive than this disease usually assumes. I saw it some hours after its first origin. It then appeared very prominent and diffuse; the inferior extremity stretched downwards over the first and second bones of the sternum, and terminated in an acute point; from hence the two external margins took a curvilinear direction upwards and outwards to the middle of the clavicle on each side, so that the tumour had a triangular appendage to it inferiorly. This appendage was elevated about three-eighths of an inch above the surface of the surrounding skin. Above the sternoclavicular articulation it was a rounded prominent tumour, extending even up to the larynx, and outwards to the margins of the sterno-cleido mastoids on each side; it had a very transparent appearance; "it looked watery" as the relatives expressed it, but the crepitant feeling experienced on handling it at once declared it to be air in the cellular tissue-emphysema. Whence came this? I was at a loss to conjecture. It struck me as probable that one of the muciparous follicles of the trachea had ulcerated through all the coats, and permitted an escape of air under the fascia. The dyspnoea rapidly increased, as also did the swelling; it at length extended to the ramus of the lower jaw; the face became livid, and the extremities cold. The child gradually passed into asphyxia, and died quietly on the 19th of August, ten A.M.

A carefully-conducted post-mortem was made on the 21st. Decomposition had not commenced. The dissection of the neck clearly showed the air to be in the cellular tissue, beneath the deep cervical fascia, and around the trachea. The whole of the cellular tissue here was emphysematous; it passed downwards, behind the sternum, into the anterior mediastinum, the cellular tissue in which was excessively distended by air. The lungs were also broken up by emphysematous dilatations. The upper lobe on the right side was most extensively disorganized by it; many of the cells were as large as currants and grapes, and all of them larger than natural. Air was proved to pass from the root of the upper lobe of the right lung into the anterior mediastinum, behind the pleura; therefore one of the distended emphysematous lobules at the root of this lobe must have given way, and allowed the air to escape into the cellular tissue in the manner described. The other organs of the thorax and abdomen presented no appearance worthy of remark; they were all anæmic. No air existed in either of the pleuritic cavities.

This case is an interesting one,-the rarity of its occurrence makes it especially worthy of note. Upon a reference to Dr. Copland's Medical Dictionary, I find that emphysema of the cellular tissue of the neck has already been noticed to occur, by two reporters, after hooping-cough: not possessing the original communications, I am unable to say whether both these cases were fatal; but from the urgent dyspnoea in this particular instance, and the irremediable nature of the injury, I must presume that it is almost impossible to be otherwise than a very fatal accident. The peculiar shape of the tumoux is at once indicative of the affection: I should now have no difficulty in recognising it again in a moment. It is evident to every anatomist that the peculiar shape is owing to the attachments of the cervical fascia to the varions salient points about the neck, which of course did not permit the air to insinuate itself under the fascia in these positions. I greatly regret that auscultation was not practised upon this little patient's thorax, to explain the cause of the dyspnoea on the 15th. Had that been done, the condition of the lung would have been detected, and the cause at once revealed. It would, however, have been impossible to have foreseen this accident; in fact, $\mathbf{I}$ should never have expected it, as, until the present case happened under my observation, I was perfectly iguorant of its existence.

Old Market-street, Bristol, 1849.

\section{ON A CASE OF POISONING BY THE ROOT OF DIGITALIS PURPUREA.}

Bx JAMES EDWARD, M.D., Surgeon, Forfar.

AMONast the numerous cases of poisoning which have hitherto been brought before the notice of the medical profession, few if any, have been caused by the root of our officinal foxglove, and it is on this account that I take the liberty of soliciting, in your valuable periodical, a corner for the following case:-

John $R-$, aged seventy, of a strong healthy constitution, when attending the plough, several years ago, in the month of April, received a blow from the stilt, on the right side of his chest, the sock of the plough having come in contact with an earth-fast stone. From this blow the parietes of that side of 
the chest were considerably bruised, but no fracture of the ribs existed.

Instead of sending for medical assistance, he, in conjunction with his relatives, on the following day, had recourse to an old woman famous in the district for the curing of bruises. This whe effected, or was said to effect, by draughts of the infusion of the root of the symphytum offieinale, or comfrey, a drug much in repute formerly as a vulnerary, but now, in this part of the country, almost forgotten; the fresh roots of it, however, are, I believe, still very often used in France, in cases of ruptrure and bruises.

On being called, our sapient dame proceeded towards the invalid's residence, carrying along with her some two ounces of her supposed comfrey-root, newly dug from the ground, which she infused in a quart of boiling waier, with a tablespoonful of sweet butter, and caused her patient to drink the half thereof. Shortly after this dose was taken violent retchings and dimness of vision became apparent, and continued for several days, during which he gradually became excessively faint and weak. On being told of this series of symptoms, the old lady doctress said, "It is of no importance, as I have got some oxycrocion to be a batter for it."

A bout the end of this time, a friend, having called to see the patient, examined the exhumed roots, and said to those present, "This is what we call dead-men's-bells, mistaken for comfrey!" "Nae fairley," said the dying man; "it was nae sooner o'er my throat than I was affected; the stink of it will never leave my nose; there is a lump lying at my heart, and I am poisoned."

He lived from Tuesday afternoon, when the draught was taken, till the following Sabbath evening. On that evening he was removed from his bed for the purpose of getting it more properly made up, but expired in his chair.

Forfar, May, 1849

\section{ON THE ALLEGED ANTAGONISM OF AGUE AND PHTHISIS.}

By RICHARD HODGES, Esq., M.R.C.S., Rochford, Essex.

TrE assertion that ague antagonizes phthisis, appears from observation to be incorrect, or, at all events, the antagonism does not exist to the extent that many would have ns believe; for, in numberless instances, I have witnessed the development of consumption in those who were suffering from ague, and vice versâ.

This neighbourhood has the credit of being an aguish one and therefore I have the opportunity of observation. We have seen, however, ague in all parts of this country, and occasionally extensively and severely, from which one might infer that this locality is not deserving of the name ordinarily given to it. Hundreds of persons live and die here without practically knowing what the disease is, and many even consider that slight attaeks of it dispose one to longevity. If it be true that intermittent fever be continually more or less prevalent in this part of Essex, it is no less true than that phthisis abounds here to an extent at least equal to that in any other locality. It may scarcely be necessary to bring forward cases illustrating the truth of the assertion that the two diseases prevail in the same neighbourhood, or that a patient may at one and the same time be the subject of both consumption and ague. Within the last year the three following cases have fallen under my notice:- A young lady, aged seventeen, suffered from intermittent fever, who, in a short time after, died of decline. A married woman, aged twenty-nine, had, about a year and a half ago, an attack of remittent fever, and then, at intervals, ague of the tertian form. In March last $I$ again visited her, on account of a chest affection, which proved to be phthisis, and she died in A pril. Another young person, thirty-six years of age, who frequently lived in Wallasea Island, (a place favourable to the development of ague and aguish diseases, suffered from an attack of remittent fever, and subsequently became the subject of a tertian intermittent; latterly, disease of the left lung manifested itself, and she is now dying of true tubercular consumption. Whether the aguish poison delayed the appearance of the pulmonary symptoms, or hastened it, I must leave; it may have debilitated the system, and placed her constitution in circunstances favourable to the production of the disease, and it is not improbable that if there had been no ggue, consumption would not have appeared so speedily.

We all know that there are such affections as aguish apoplexy. I am now in attendance upon a person at Leigh in this neighbourhood, who has had a severe disorder of this sort, and intermittent neuralgia, and why should there not be an aguish bronchitis? I believe that there is such a disease, and it is more than probable that this malady-aguish bronchitis-may have been mistaken for phthisis, and the ague, or its cause obtained the credit of being an antagonist to what was supposed to be consumption; whereas, in reality, the pulmonary symptoms might have been, or were, the result of the cause of ague, and bona fide of like origin with it.

It has not been my wish, Sir, in transmitting this communication to you, to differ from those eminent men who have advoeated the doctrine that ague and phthisis are opposed to each other, but to caution those who have been educated to believe in the antagonism not to pronounce a person with ague to be free from phthisis, or assert, that because a person labours under intermittent fever he never will die of eonsumption.

Rochford, May, 1849 .

\section{SOME OBSERVATIONS ON THE EPIDEMIC} FEVER OF 1847,

AS IT OCCURRED IN AND ABOUT UISBURN, COUNTT ANTRIM, IRELAND; WITH A SHORT HISTORICAL NOTICE OF SIMILAR EPIDEMICS IN THAT COUNTRY, AND THE LEADING CHARACTERISTICS WHICH THEY SEVERALLY RXHIBITED.

\section{By JOHN JOHNSTON KELSO, M.D., Lisburn.}

" Profecto sola observationum frequentia primam mihi suspicionem.for" mavit ne res sic, ut credebatur, se haberet. Suspicio hæc reddidit me proprize opinioni diffidentem s diffidentia ad maturius compulit examen."-DE HAEN, RAT. MED., vel. iii. p. 240, 1768 .

"Animadvertendum autem est, epidemicorum alios in hoc aut illo anno regulariter et eodem semper modo se habere, iisdem plane phænominis et conformi symptomatum agmine in plerisque fere omnibus quos adoriuntur, stipatos; atque eadem prorsus via sibi fugam et exitum parantes. $\mathbf{E x}$ his itaque tanquam in suo genere perfectissimis, vera ea certa morborum epidemicorum historia ediscenda est atque tradenda." - SyDENHAM, DR MORBIS EPIDEMICIS.

\section{(Continued from vol. ii. $1848, \mathrm{p}, 667$ )}

As in Egyptian plague, so in Irish typhus, those on whom Fortune has shed more grudgingly of her favours, or has entirely abandoned to the gaunt family of "want, misery, and wo," afford the chiefest pabulum, so to speak, which serves to maintain and perpetuate'it in perennial vigour, both in nonepidemic and epidemic periods. So true is the fact of the immensely greater diffusion of fever, in one or other of its forms, among the lower orders in this country, at all times and in all places, that science, on data the most irrefragable, may safely claim it as a law, and in the epidemic, of which we are essaying a local, but necessarily incomplete description, we discover an additional fact in exemplification. For assuming, as we have reason to do, that the population of the town of Lisburn, and the manor of Derrivolgie, in which it is situate, with that of the adjoining one of Kilultagh, (for the exclusive use of which the fever hospital here was originally instituted, numbers 20,000 persons, and that three-fourths of these are, or were at the time of its invasion; individually so circumstanced as to be placed without resource to the hospital in the contingency of an attack of fever, it will appear, on reference to the foregoing return, that of the remaining fraction of 5000 , presumptively, there are recorded 1549 cases of admission within its walls. But the return scarcely embraces the whole period of the epidemic eonstitution; had it done so, and had all the patients in the locality requiring hospital care been transferred to its wards, the amount of seizures in this class of the community can hardly be corsidered as having fallen short of 2000 , or two out of every three persons composing it.* In the better ranks of life, however, experience, in accordance with prior observation; afforded a very different result; among them the disease, in fact, was comparatively limited; yet, as is equally common, and in some sort compen. sative, as it would seem, it at the same time almost invariably presented itself with some aggravation of type, not uncommonly with all the distinctive symptoms of malignancy, and a proportionately high relative mortality.

But in order to evidence more fully the extensive diffusion here of fever, in 1847 , it is necessary to take into account the degree of its usual-one might almost say normal-prevalence among us. Some idea of this may be formed from a return of this charity with which $I$ have been favoured, + extending as it does over a period of fourteen years-namely, from - 1833 to 1846 , inclusive, and from which it appears that the average number of patients treated in it during that time computes

* In the fever of 1817 , during the two years of its prevalence, it is believed that, in Cork, over one-seventh of the inhabitants passed throngh the disease.-(Barker and Cheyne, loc cit., vol. ii. p. 26.) $\dagger$ By Mr. Campbell. 